The Price of Democracy 



\title{
The Price of Democracy
}

HOW MONEY SHAPES POLITICS

AND WHAT TO DO ABOUT IT

\author{
JULIA CAGÉ \\ Translated by Patrick Camiller
}

Harvard University Press $_{\text {Hen }}$

Cambridge, Massachusetts, and London, England 2020 
Copyright (c) 2020 by the President and Fellows of Harvard College All rights reserved

Printed in the United States of America

\section{First printing}

Cover design: Annamarie McMahon Why

$$
\begin{gathered}
9780674246119 \text { (EPUB) } \\
9780674246126 \text { (MOBI) } \\
9780674246133 \text { (PDF) }
\end{gathered}
$$

First published in French as Le prix de la démocratie, Fayard, Paris (C) Librairie Arthème Fayard, 2018

Preface first published in the paperback edition of Le prix de la démocratie, Gallimard, Paris

(C) Julia Cagé, 2020

Cataloging-in-Publication Data available from the Library of Congress ISBN: 978-0-674-98728-9 (alk. paper) 